\title{
SEM AND PCR STUDY OF MYCORRHIZAL FUNGI ISOLATED FROM THE AUSTRALIAN TERRESTRIAL ORCHID: PRASOPHYLLUM
}

\author{
Emily McQualter ${ }^{1,3,4}$, Rob Cross $^{2}$, Cassandra B. McLean ${ }^{1} \&$ Pauline Y. Ladiges $^{3}$ \\ 'Burnley College, The University of Melbourne, 500 Yarra Boulevard Richmond, Victoria, Australia 3121 \\ ${ }^{2}$ Royal Botanic Gardens Melbourne, Birdwood Avenue South Yarra, Victoria Australia 3121 \\ ${ }^{3}$ School of Botany, The University of Melbourne, Parkville, Victoria, Australia 3052. \\ ${ }^{4}$ Author for correspondence: e.mcqualter@pgrad.unimelb.edu.au
}

Most members of the genus Prasophyllum (Leek Orchids) are threatened and restricted in distribution in Australia. Prasophyllum species are obligate mycotrophic plants and current conservation protocols for terrestrial orchids in Australia require propagation with symbiotic mycorrhizal fungi. Unfortunately there is a paucity of knowledge regarding the mycosymbiont in this genus, hampering conservation and re-introduction efforts.

Before recovery plans can be implemented for Prasophyllum basic biological information is required about the nature of the mycorrhizal relationship. This study used two threatened Prasophyllum species: $P$. sp. aff. validum and $P$. diversiflorum, both from south-west Victoria. Prasophyllum sp. aff. validum grows in a low open grassy heathland and Prasophyllum diversiflorum (Gorae Leek Orchid) is found in open grassy, swampy vegetation.
Underground plant parts were collected for mycorrhizal isolation and Scanning Electron Microscopy (SEM) studies. Mycorrhizal fungi were isolated from adult plants at four times during the year: soon after leaves appeared following summer, during the period of flower bud growth (Winter), while flowering (Spring) and as the fruit developed (Spring) SEM was used to determine the location, type and amount of mycorrhizal colonisation. The ability for the isolated fungi to germinate seed was tested with seed collected from plants in 2005. As most mycorrhizal fungi from Australian terrestrial orchids do not sporulate in culture and therefore cannot be identified by normal taxonomic means DNA from fungal isolates were ITS-sequenced and closest GenBank matches were determined. The information gained in this study will provide the basis for further re-introduction and conservation studies. 